\title{
Comparision of Two Different Vaccination Shedule for Fight with Infectious Bursal Disease in Layer Hens
}

\author{
Ahmet Bildir'1, Sibel Gür ${ }^{2}$ \\ ${ }^{1}$ Kartallar Limited Company, Afyonkarahisar, Turkey. \\ ${ }^{2}$ Faculty of Veterinary Medicine, Department of Virology, Afyon Kocatepe University, Afyonkarahisar, Turkey.
}

Geliş Tarihi / Received: 29.09.2017, Kabul Tarihi / Accepted: 10.11.2017

\begin{abstract}
Infectious Bursal Disease Virus (IBDV) is one of the most important immunosuppressive diseases of poultry which classified in Avibirnavirus genus belonging to Birnaviridae family. In this study, two different vaccination schedules were compared in the aspect of protectivity. For this purpose, blood serum samples was collected from 6 flocks of layer chickens in the postnatal period on days $0,7,14,21,28,35,42,49,56,63$ and 70 . Samples were randomly selected from 10 chicks in every sampling. Flock 1 was sampled two more times due to acute clinical infection. The total of 680 serum samples was tested for IBDV specific Antibody (Ab) presence and titers using ELISA. Maternal derived antibody (MDA) was found to be protective for 6-8 days. Standard vaccination schedule (one inactive and three live intermediate vaccines) was carried out at three flocks (2, 3 and 5). In other flocks, one live, one inactive and additional more live vaccine were administered to the chicks into water. Despite regular vaccination, IBD epidemic was seen in flocks 1 and 2. In flock 1, an outbreak was reported with 23\% mortality in previous breeding period. This proportion was reduced to $4.5 \%$ in this enterprise by applying initially live vaccine, and then any sign of clinical infection has not been detected. Antibody titers were entered augmentation trend in flocks 1 and 2 until day 21. probably due to viral load, this turning point was detected on day 14 in other flocks. Statistical analysis clearly showed that MDA titers showed a sharp decrease in the initially live vaccine given flock. In conclusion, to stimulate cellular immune response using initial live dose as soon as possible is more influential. It means, changing standard vaccination schedule was found to be more effective on protection of animals in the critical period of infection, especially in the presence of viral load in the field.
\end{abstract}

Keywords: Infectious bursal disease, Maternal derived antibody, Virus, Vaccination.

\section{Yumurtacı Tavuklarda Infectious Bursal Disease ile Mücadelede İki Farklı Aşılama Programının Karşılaştırılması}

Özet: Infectious Bursal Disease Virus (IBDV) Birnaviridae familyasının Avibirnavirus genusunda sınıflandırılmış olan kanatlıların en önemli immunsupresif hastalıklarından biridir. Bu çalışmada, iki farklı aşılama programı koruyuculuğu açısından karşılaştırıldı. Bunun için, 6 yumurtacı sürüden portnatal 0, 7, 14, 21, 28, 35, 42, 49, 56, 63 ve 70 . günlerde kan örnekleri alındı. Her örneklemede rastgele seçilmiş 10 civciv örneklendi. Akut klinik enfeksiyon gelişmesi üzerine sürü 1 iki kez daha örneklendi. Toplam olarak 680 serum örneği IBDV spesifik Ab varlığı ve titresi açısından ELISA ile test edildi. Maternal Antikorların (MA) 6-8. günlere kadar koruyucu olduğu belirlendi. Standart aşılama program (1 inaktif ve 3 canlı intermediate aşı) 3 sürüde uygulandı (2, 3 and 5). Diğer 3 sürüde, civcivlere bir canlı bir inaktif ve ek olarak bir canlı aşı içme suyuna karıştırılarak verildi. Düzenli aşılama yapılmasına rağmen sürü 1 ve 2'de IBD salgını görüldü.

Bir nolu sürüde bir önceki yetiştirme döneminde $\% 23$ mortaliteli bir salgın kayıt edilmişti. Bu oran aynı sürüde canlı aşı uygulamasıyla \%4.5'a düşürüldü ve hiçbir klinik enfeksiyon tespit edilmedi. Antikor titreleri 1 ve 2 nolu sürüde muhtemelen viral yük nedeniyle 21. güne kadar artış eğiliminde iken diğer sürülerde bu dönüş noktasının 14. gün olduğu tespit edildi. İlk olarak canlı aşı uygulanan sürülerde maternal antikor titrelerinde ani bir düşüş gerçekleştiği istatistiksel analizlerle açıkça gösterilmiştir. Sonuç olarak, aşı takvimini değiştirmek anlamına gelen, hücresel immun yanıtı mümkün olduğunca erken bir şekilde uyarmak için ilk dozun canlı aşı olarak kullanılmasının, enfeksiyonun kritik dönemlerinde ve özellikle de sahada akut viral enfeksiyon söz konusu olduğunda etkili bir koruma sağlayabileceği belirlendi.

Anahtar Kelimeler: Aşılama, Infectious bursal disease, Maternal Antikor, Virus

\section{Introduction}

Infectious Bursal Disease Virus (IBDV) was classified in Avibirnavirus genus belonging to
Birnaviridae family. There are two viruses in this group; IBDV in chicken and Infectious pancreatic necrosis virus in fish [24]. Birnaviruses have ico-

*Aynı isimli Yüksek Lisans Tezinden Özetlenmiştir

Yazışma adresi / Correspondance: Sibel Gür, Department of Virology, Faculty of Veterinary Medicine, Afyon Kocatepe

University, ANS Campus, Afyonkarahisar,Turkey E-mail: sibelgur@aku.edu.tr 
sahedral symmetry. Genome composes of linear double stranded RNA with two segments.

There are two distinct serotypes of IBDV, only type 1 is pathogenic. Both serotypes may infect fowl [3] and ducks [28], but clinical findings may only be seen in chicken. The primer replication site is $\mathrm{B}$ lymphocytes and target organ is Bursa Fabricius. Transient immunospression could be seen after acute infection or vaccination with live vaccines. Additionally, secondary infections and low level of Antibody ( $\mathrm{Ab}$ ) formation are potential problems in this period. Type 2 may be propagated the many different tissue type but none of the isolates are immune suppressive [35].

Immune suppression related problems are cause to economic loss via increase in sensitivity against other infectious agents $[1,11,25]$ and low level $\mathrm{Ab}$ responce to any kind of vaccines [42]. Chickens need to be protected especially during first 6 week of their life which is the most critical period in the aspect of the infection.

The agent was in circulation in many regions of America in 1960s [23], later on the infection was reached to continental Europe between 1962 and 1971 [10] and continued to spreading. Today, the presence of infection has been reported in many parts of the world [22]. According to an investigation conducted by Office of International des Epizooties in 1995 in 65 countries, 95\% have the infection [9]. After emerging of very virulent strains of type 1 in America, Europe and Asia in 1990s, fighting with the IBDV has become an obligation $[33,39]$.

The IBDV may be survived in farm material up to 122 day [5]. Resistant features of IBDV under environmental conditions and wide geographical distributions are creates an obligation to continuously fight with IBDV. Hygienic measures are quite advisable but generally not sufficient alone [5]. Vaccination has been accepted as only effective method [26]. Protective level of Ab may be achieved by with live or inactivated vaccines. The type of vaccine and the vaccination programme should be determined according to the potential risk of transmission status, virus strain, maternal antibody level (MDA) and heterogeneity of flocks. Inactivated vaccines have been using widely and successfully but not totally preventive against infection with high virulent strains. Classical live vaccines creates lifelong protection but reactivation possibility and immunosuppression risk are limiting the usage of hot vaccines [15,29]. Intermediate type vaccines have been preferred due to providing efficient $\mathrm{Ab}$ level and relatively low side effects. As a common apply, hens has been vaccinating with an oil-emulsion vaccine before laying to create passive immunity at the offspring [42].

The IBDV was initially detected in a broiler flock in 1978 in Turkey [21]. Later on, the virus was isolated during an outbreak [8]. Serologic studies were revealed presence of up to $78 \%$ proportions from different parts of Turkey [2,4,34]. Türe ve Çöven [41] were determined antigenic similarities among field isolates. Mortality was nearly $2-5 \%$ in 1983-1992, after 1993, up to $50 \%$ and $80 \%$ mortality was observed in broiler and layer hens. IBDV is still among most important problem disease in fowl in Turkey.

Vaccination is a routine application for the prevention of IBDV infection by live or inactive vaccines. However, routine vaccinations schedule apply and hygienic precautions were not totally preventive. Therefore, aim of this study was to investigate the effect of different vaccination strategies in the prevention of IBDV infection in both healthy and outbreak detected flocks via monitoring MDA and vaccine related $\mathrm{Ab}$ titer alterations.

\section{Materials and Methods}

\section{Study design and sampling}

In this study, blood serum samples were collected from 6 different layer flocks in Afyonkarahisar province, Central Anatolia. Every flock were sampled 11 times on $0,7,14,21,28,35,42,49,56,63$ and 70 days. Blood samples have been drawn from randomly selected 10 chicks. Flock 1 was sampled two more times on 33. and 80. days. Total of 680 samples was obtained.

Vaccination schedule was started with inactive vaccine and continued with live intermediate on flocks 2, 3 and 5. In other three flocks, live vaccine was administered initially, and then one inactive and two live vaccinations have been applied (Table 1). Same vaccines have been used in whole studied flocks. Inactive vaccine was administered via injection as subcutan $(0.5 \mathrm{cc} /$ per chiken $)$. Live interme- 
diate vaccines have been given via drinking water. Before the vaccinations, drinking water was withhold for two hours to allow animals to get thirsty. The dosages were counted according to the number of chickens and mixed into the de-chlorinated tap water in a consumable quantity within $2 \mathrm{hr}$.

Table 1. Vaccination programme of the flock (Day/ Vaccine Type)

\begin{tabular}{ccccc}
\hline Flock no & First dose & Second dose & Third dose & Fourth dose \\
\hline 1 & 6. L* & 7. I** & 14. L & 21. L \\
2 & 7. I & 14. L & 21. L & 27. L \\
3 & 8. I & 13. L & 20. L & - \\
4 & 7. L & 10. I & 15. L & 22. L \\
\hline 5 & 7. I & 11. L & 18. L & 26. L \\
6 & 8. L & 11. I & 15. L & 21. L \\
\hline
\end{tabular}

${ }^{*} \mathrm{~L}$; Live vaccine, ${ }^{* *} \mathrm{I}$; Inactive vaccine

Typical IBDV clinical symptoms were observed in flocks 1 and 2 during sampling period. Clinical disorders and postmortem findings were determined in chicks such as watery white diarrhoea, depression, haemorrhagie in legs and pectoral muscules, and proventriculus-vetriculus transition and enlargement in Bursa fabricius. Cross-section of Bursa fabricius was oedematous and petechial haemorrhagies covered with yellowish transudate.

\section{Serological Examination}

To examine of the serum samples for IBDV specific antibodies and titer, ELISA was preferred due to high sensitivity and specifity [7, 20, 27]. The obtained samples $(n=680)$ were examined for IBDV specific antibodies using an indirect ELISA test kit (Synbiotics, USA). Test was performed according to the producer's instructions and plates were read in $405 \mathrm{~nm}$ filter. Obtained Optic Density (OD) data were evaluated in accordance with manual.

\section{Statistical Analysis}

Analysis of Covariance (ANCOVA) was used to compare the different vaccination procedure. This test has been used to determine the variability of dependent variable, that explained by both categorical and continuous independent variables. Because of starting $\mathrm{Ab}$ titres are different on a flock basis, day 0 values were accepted as covariate.

\section{Results}

\section{Serological test results}

In flock 1 , vaccination was started with live vaccine administration on day 6 , inactive applied on day 7 and continued with live vaccine on days 14 and 21 . IBDV epidemic was detected on day 33 and lasts for 6 days with $4.5 \%$ mortality. As can be seen in figure 1 , a sharp decrease was observed on MDA level as a result of live vaccine but an uptrend shown after day 28.

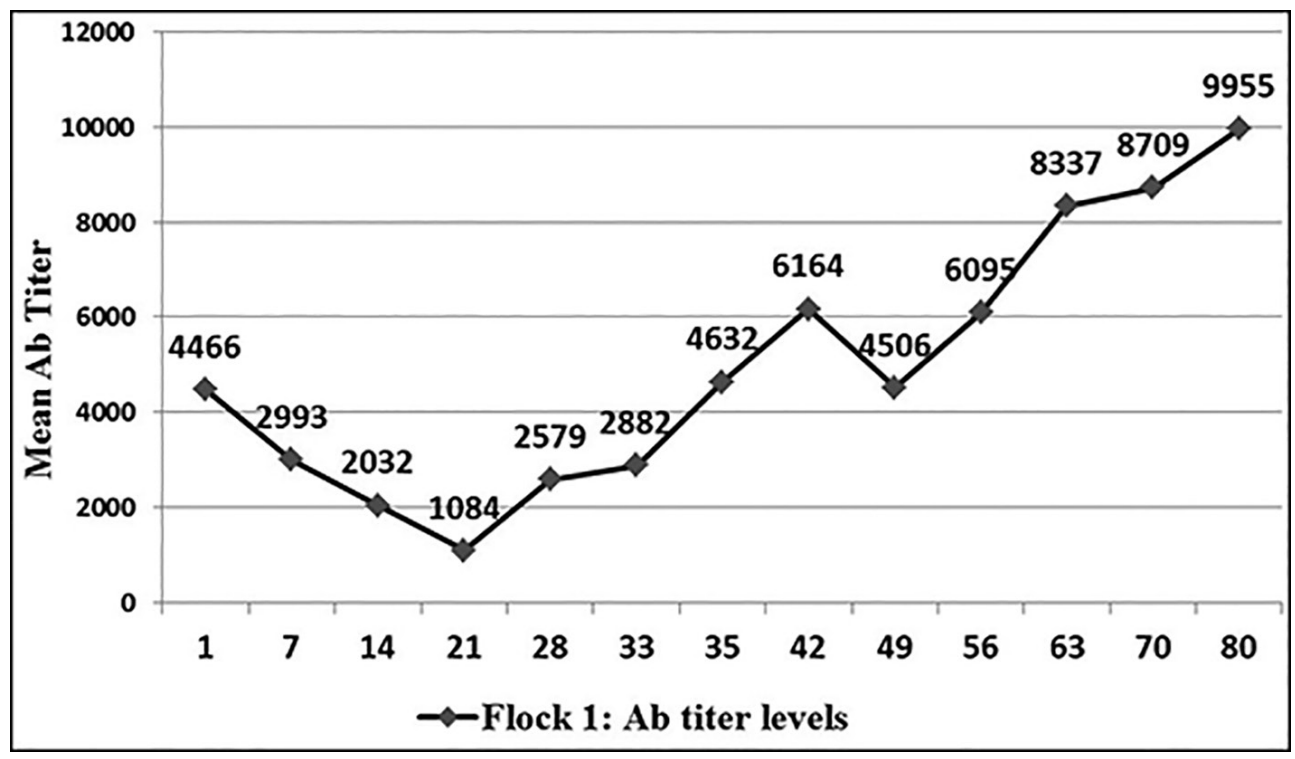

Figure 1. Mean $\mathrm{Ab}$ titer data according to the days of sampling of Flock 1 
In flock 2, inactive vaccine was applied on day 7 , whereas live vaccine was given on day 14 . Then, live vaccine was administered on day 21 and 28. By the way, clinical disorders have been observed between days 8 and 37 . Mortality was $8.5 \%$ and the Abs turning point was detected on day 21.

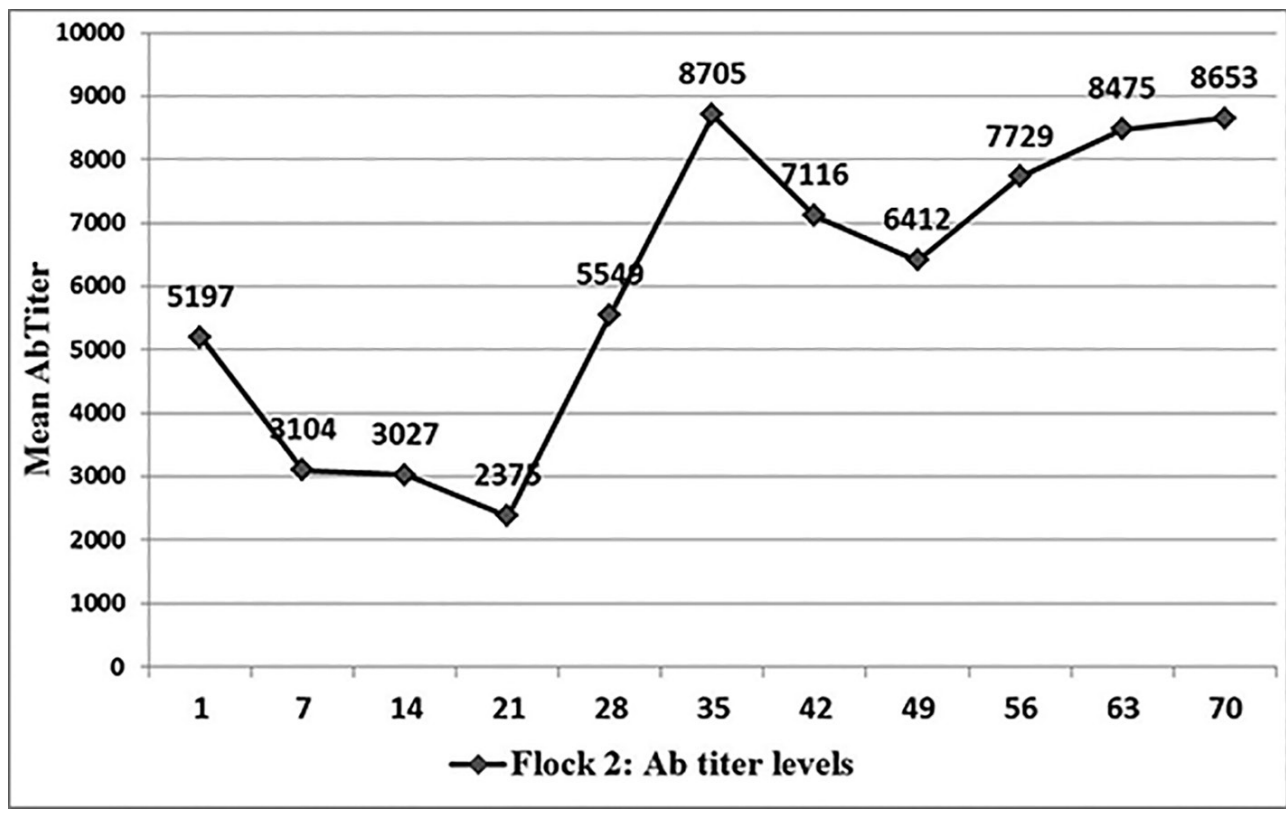

Figure 2. Mean $\mathrm{Ab}$ titer data according to the days of sampling of Flock 2

Schedule began with inactive vaccination on day 8 in flock 3 and two more live vaccine adminis- trated on days 13 and 20. Ab titer was entered into the rising trend after day 35 .

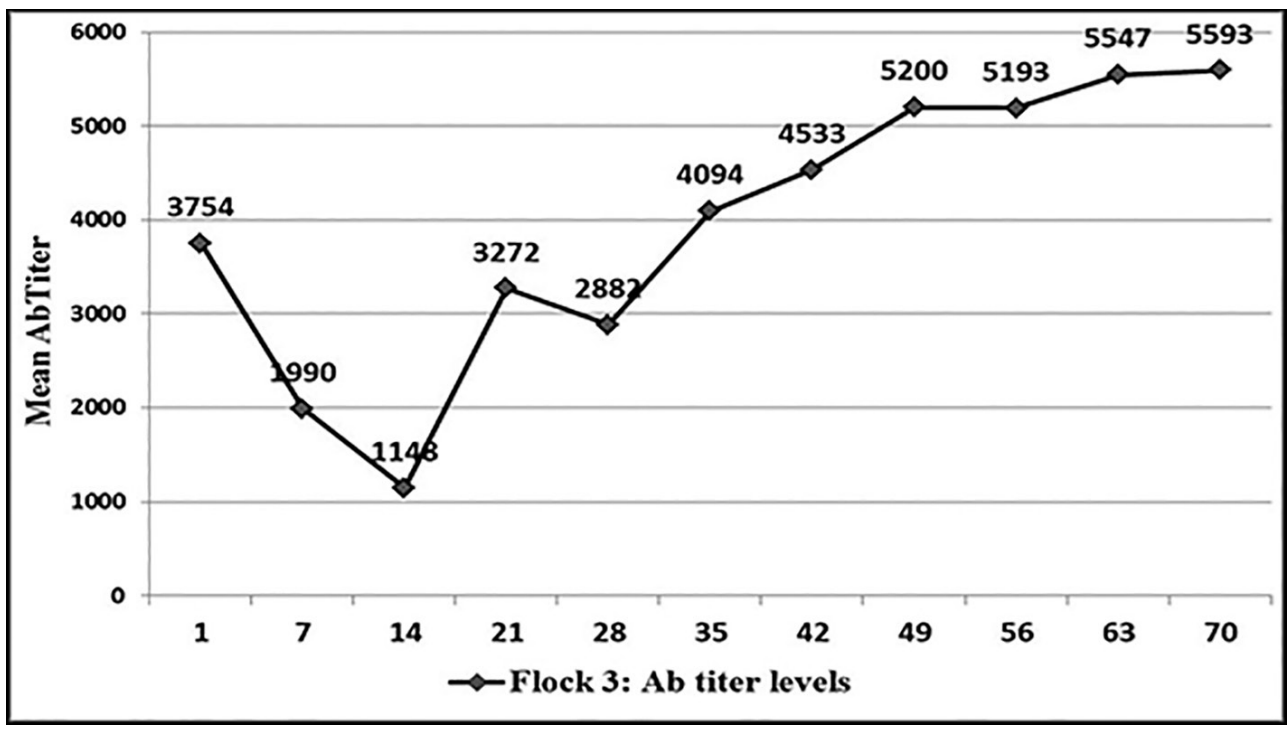

Figure 3. Mean $\mathrm{Ab}$ titer data according to the days of sampling of Flock 3

Flock 4 were vaccinated using live type on day 7. One inactive and two live vaccines were in subsequent days 10, 15 and 22, respectively. Ab level was entered regular increase trend after day 35 like other flocks (1 and 6) that initially live vaccine applied. A small transient decrease was determined on 10. sampling in day 63. 


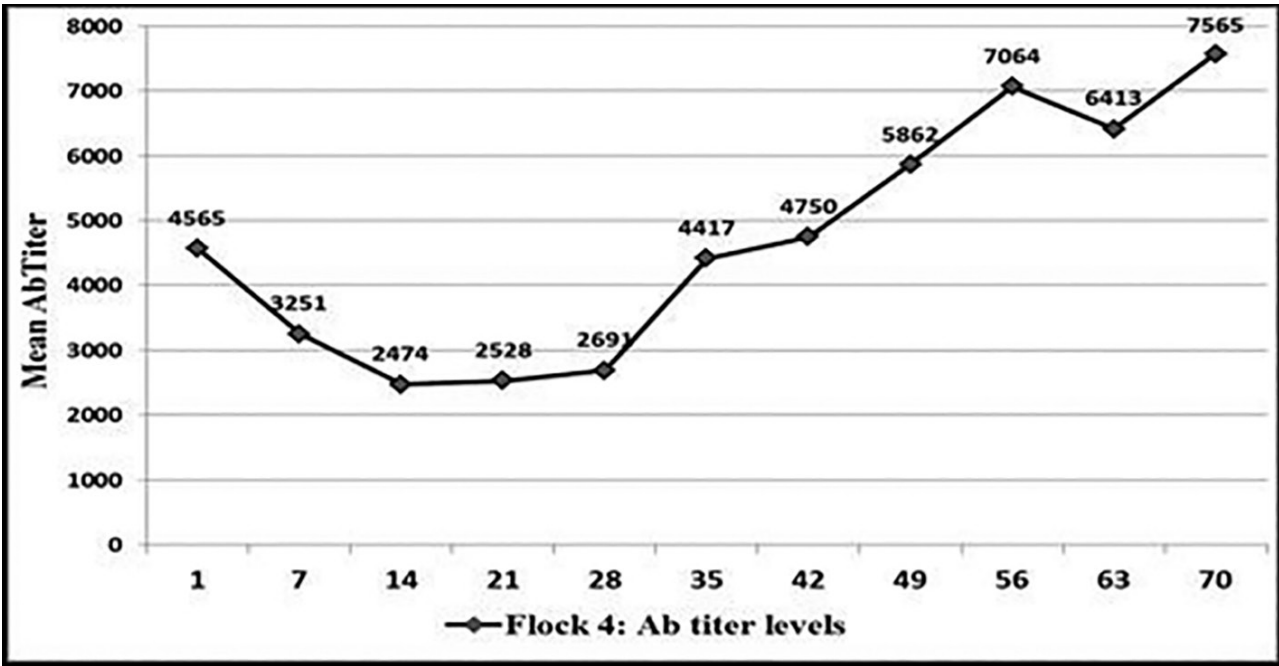

Figure 4. Mean $\mathrm{Ab}$ titer data according to the days of sampling of Flock 4

Inactive vaccine was administered in day 7 in flock 5, program was continued with three more live vaccine administration in days 11,18 , and 26 .

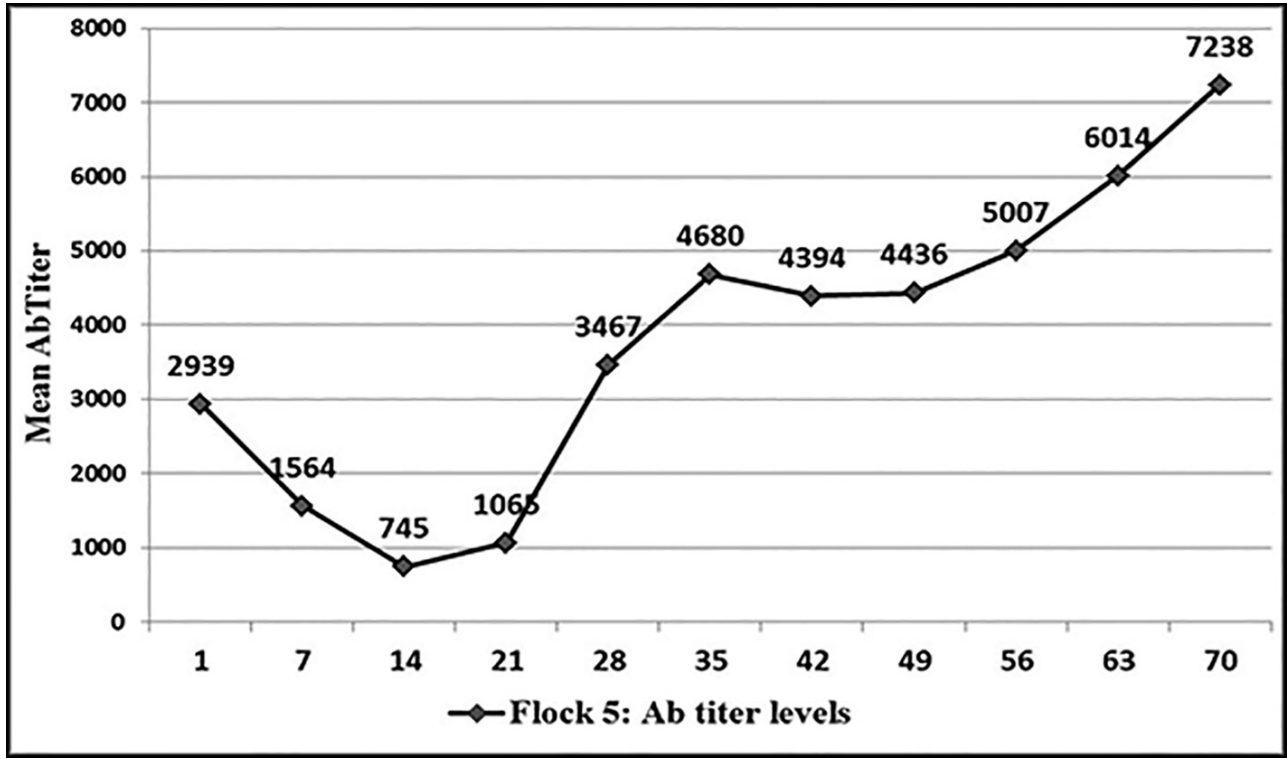

Figure 5. Mean $\mathrm{Ab}$ titer data according to the days of sampling of Flock 5

The most regular changes were detected in flock 6 , live vaccine usage on 8 . day caused to rapid decrease in titer level. Vaccination program was continued with inactive on day 11 and live vaccine administered on days 15 and 21. As can be seen in figure 6, a rapid decrease was observed on day 63 . Chickens were separated to two groups on day 56 for lessen the flock intensity. Ab levels showed increase again after day 70 . 


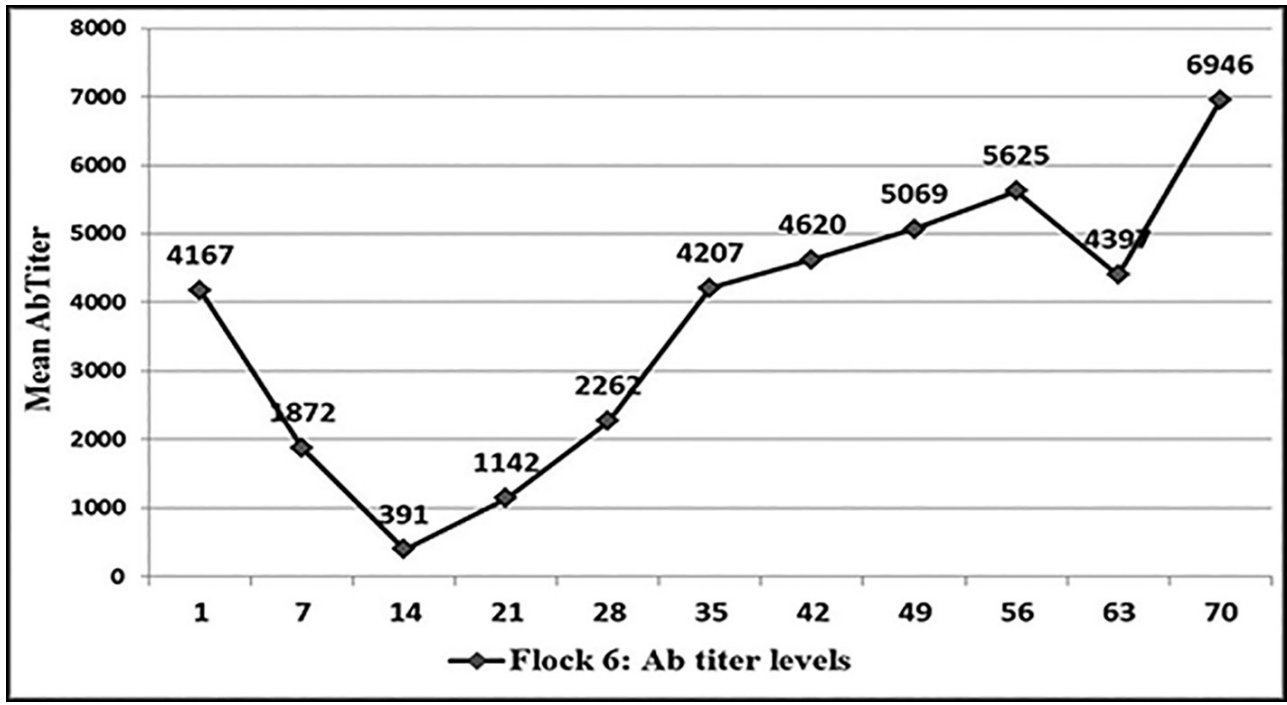

Figure 6. Mean $\mathrm{Ab}$ titer change according to the days of sampling of Flock 6

\section{Statistical Analysis}

As a result of ANCOVA analysis, differences was determined between two groups, Ab titer level was lower in three flock $(1,4,6)$ with live vaccine used initially $(\mathrm{p}<0.05)$.

\section{Discussion}

After first isolation in Gumboro district in Delaware in 1957 [6], IBDV infection was disseminated to many parts of the world but has been taken under control by regular vaccinations. However, the outbreaks are still being reported and causes to economic loss. To achieve enough level Ab titer via immunisation under field condition has been accepting as a main strategy [12].

In this study, Ab titer changes was monitored via regular sampling in different vaccination schedule applied 6 layer hens flock in this study.

IBDV infection was detected clinically with $23 \%$ mortality in previous breeding season in flock 1. Typical clinical disorders were observed again in the sampling performed breeding season on day 33 . and lasts for 6 days but mortality reduced to $4.5 \%$. Live intermediate vaccine was used as initially contrary to previous breeding season in 6 . day, 1 day later inactive and live vaccine was applied again on 14. and 21. days. Ab was continued the decrease up to 21 . day and a sharply turned to up continuously except in 49-56. days interval. The flock was vaccinated for Salmonella gallinarum via injection in 46 . days, later on a transient immunosuppression was observed probably due to handling stress. As can be seen in fig 1., a permanent increase and highest titer level was detected in this flock on 70. day. Both vaccination and natural infection seems stimulated the immune response strongly (Fig 1).

There has been no clinical IBDV history of flock 2 but an epidemic was arosen on 37. day. Clinical infection process was recorded as 8 days and mortality value was $8.5 \%$. Despite quite high Abtiter (8.705) presence on day 35, two days before onset of the epidemic, happening mortality value was not low. Probable reason would be immune heterogeneity of the flock. Vaccination was started with inactive and continued with administration of live doses on days 14., 21. and 28. Titer level turn point was observed on day 21 like in flock 1, later on fluctuated in the course of clinical disorders observed period due to viral load (Fig 2).

IBDV infection was not observed in other studied flocks. One dose inactive and two live vaccines were applied in flock 3 (Fig 3). Turn point was detected in 3. sampling on day 14 and a sudden decrease observed sampling day 28 . There would be two probable reason; flock would be exposed the virus and lost their antibodies or presence of undetected stress factor. However, there is no data to prove the both probability.

Vaccination was started with live intermediate in flock 4. Despite ordinary titer changes was observed in this flock, as can be seen in fig. 4, a 
transient decrease was determined in day 63 of sampling just after injectable vaccination apply in day 58 for Salmonella gallinarum.

Ab level changes were detected as expected in flock 5 until day 35 (Fig 5). However, inadequate $\mathrm{Ab}$ increase observed from this point. On the controlling farm records, rise in temperature was detected in the middle of sampling period (end of the July). Heat stress would have been created immunosuppression.

Live vaccine was applied as first vaccination in flock 6 , after a short rapid decrease, titer entered the augmentation trend from 14. days but a sharp transient downturn shown in 63. day sampling (Fig 6). This decrease was eventuated after dividing flock as two distinct groups to make rarefy. It is obvious that handling stress was effected the immune response.

Main factors of the epidemics in poultry farming are inappropriate disinfection, deficiency in management practises, wrong vaccine type and wrong timing applies are The infection may be seen more severe and earlier in next breeding period $[5,36]$.

The most feasible method for prevention of IBDV infection in the field is vaccination. However a unique vaccination programme cannot be proposing due to variability of MDA, and other factors related to management and environmental conditions. Vaccination would be unnecessary in broiler flocks keeping in strictly controlled closed breeding management conditions. Additionally, have high level MDA seems sufficient in their short life span. However, active immunoprotection is quite necessary in layer hens. To determine the right vaccination schedule is the most critical decision and has vital importance. The most important parameter on the successful immunisation is to get obtain homogeny in MDA titer at the beginning. In the field, controlling of $\mathrm{Ab}$ titer level is a routine work but, in most of the time, not gives enough information in the aspect of flock homology due to arbitrarily sampling style.

Main aim of the vaccination is to supply optimal $\mathrm{Ab}$ titer level in the critical period of IBDV infection (25-45 days). MDA is protective in the first 6-8 days of life, and end of first week of life was regarded as suitable time for initial vaccination.
Inactive vaccines have been preferred as first vaccination due to in case of no viral challenge risks. Live vaccines are stimulates the cellular immune system and stronger Ab level may be achieved. Commonly using schedule is 1 inactive and 2 or 3 doze live vaccine apply but this schedule may not be feasible in the presence of the virus in and around the farm. In the flock 1, 23\% mortality was recorded in previous breeding period despite standard vaccination program. After changing schedule, this proportion was reduced to $4.5 \%$ in the sampling performed course and no infection was aroused in the subsequent breeding period. Considering presence of the virus in the farm and resistant character of the agent under field conditions, rearranging of vaccination style seems effective on prevention of economic looses. IBDV Ab titer decrease has been continued to day 14 of postnatal period on 4 flocks $(3,4,5$ and 6$)$. After live vaccine apply in day 14 , trend was entered the increase. Turn point was detected as 21 . day on the flocks 1 and 2, probably due to environmental viral load. Two dose live vaccine has been administration in days 15 and 26. resulted with fast and ordinary titer increase in all of the flocks. In this period, statsistical difference was not determined between different schedule used flocks.

Goddard et al. [13] was vaccinated the four group of chicks with different combinations of commercial inactivated and live vaccines. Only a dose of live vaccine administered group was detected as susceptible to the viral challenge up to seven week of life. Besides, bot vaccination schedule were found to be protective against experimental viral challenge.

However, initially live vaccine administered groups were found to be safer in this study. Decrease in mortality was observed in flocks 1 and 2 that clinical infection emerged accidentally.

The most of the experimental studies for determining optimal vaccination period were carried out in broiler. Half life of MDA has been evaluated differently according to breeding aim and management conditions. To determine the right schedule for vaccinations is not easy under field conditions. Interference of vaccine virus by MDA is the greatest risk and cause to retardation or prevention of immune response to the vaccine $[40,43]$. MDA level, half life of MDA, breeding aim, sampling days, the 
$\mathrm{Ab}$ titer uniformity of the flock and vaccine type like factors have to be considered to determine the most suitable vaccination schedule using Deventer formula [7].

Correlation among stress factors and immune response is a well known phenomenon. Cortisone is one of the best known immune suppressor substances. Fear stimulates the amygdala and leads to cortisone secretion. This correlation was proved in more than 20 species. As can be obviously seen in this study, human manipulations have transient but strong negative effect on the immune response. Even though there was no clear description on this issue, stress related growth retardation $[17,18]$, impairment in immune response $[14,16,30]$, productivity problems were reported before [17,38]. To avoid from manipulative performances after the vaccinations is a necessity to obtain expected results.

Epidemics could be emerged despite routine vaccination programme and disinfection precautions. Any risk factors would not be detected in some cases. In this kind of situations, management conditions and other less important factors for transmission should be taken into consideration like birds, fly (Aedes vexans) [19], mealworm (Alphitobius diaperinus) [37], dogs and rodents [25,31,32].

In conclusion, IBDV $\mathrm{Ab}$ titer changes were monitored in two different vaccination programs applied groups of flocks. Prevention of epidemics and eliminate the economic losses could be more feasible via stimulating cellular immune response as soon as possible with initially live vaccine administration considering half-life of MDA.

\section{Acknowledgement}

The authors thanks to Dr. Nurhan Doğan for contribution to study with statistical evaluation.

\section{References}

1. Allan WH, Faragher JT, Cullen GA, (1972). Immunosupression by the infectious bursal agent in chickens immunized against Newcastle disease. Vet Rec. 90, 511-512.

2. Babila A, Ası Y, Akçadağ B, Gürel A, (1988). Ístanbul ve Trakya Bölgesi kümes hayvanlarında IB, ILT, IBD, EDS, $A E$ ve adenovirus enfeksiyonlarının epizootiyolojik araştırması ve izolasyon çalışmaları. Pendik Hay Hast Arş Enst Derg. 19, 6-77.
3. Barnes HJ, Wheeler J, Reed D, (1982). Serological evidence of infectious bursal disease virus infection in Iowa turkeys. Avian Dis. 26, 560-565.

4. Baysal T, Bozkır M. (1989). Konya Bölgesi kümes hayvanlarinda IBD, ILT, EDS, IBD, AE, ve adenovirus enfeksiyonlarının epizootiyolojik araştırılması ve izolasyon çalışmaları. Etlik Vet Mikrobiyol Derg. 6, 23-30.

5. Benton WJ, Cover MS, Rosenberger JK, Lake RS, (1967). Physicochemical properties of the infectious bursal disease agent (IBA). Avian Dis. 11, 430-438.

6. Cosgrove AS, (1962). An apparently new disease of chickens-Avian Nephrosis. Avian Dis. 6, 385-389.

7. De Wit JJ, (1999). Gumboro disease: optimising vaccination. Int Poult Prod. 7, 19-21.

8. Ergün A, (1989). Tavukların bazı viral hastalıklarının epizootiyolojik taramasinda kullanılmak üzere antijen ve antiserum hazırlanması. Etlik Vet Mikrobiyol Derg. 6, 35-54.

9. Eterradossi N, (1995). Progress in the diagnosis and prophylaxis of infectious bursal disease in poultry. OIE, Paris, France, p.75-82.

10. Faragher JT, (1972). Infectious bursal disease of chicken. Vet Bull. 42, 361-369.

11. Faragher JT, Allan WH, Wyeth CJ, (1974). Immunosupressive effect of infectious bursal disease agent on vaccination against Newcastle disease. Vet Rec. 95, 385-388.

12. Fussel LW, (1998). Poultry industry strategies for control of immunosuppressive diseases. Poult Sci. 77, 1193-1196.

13. Goddard RD, Wyeth PJ, Varney WC, (1994). Vaccination of commercial layer chicks against infectious bursal disease with maternally derived antibodies. Vet Rec. 135, 273-274.

14. Grandin T, (1997). Assessment of stress during handling and transport. J Anim Sci. 75, 249-257.

15. Guittet M, Le Coq H, Picault JP, Eterradossi N, Bennejean G, (1992). Safety of infectious bursal disease vaccines: assesment of an acceptability threshold. Dev Biol Stand.79, 147-152.

16. Hastings BE, Abbott DE, George LM, (1992). Stress factors influencing plasma cortisol levels and adrenal weights in Chinese water deer (Hydropotesinermis). Res Vet Sci. 53, 375-80.

17. Hemsworth PH, Barnett JL, (1989). Relationships betweenfear of human productivity and cage position of laying hens. Br Poult Sci. 30, 505-518.

18. Hemsworth PH, Coleman GL, Barnett JL, Borg S, (2000). Relationships between human-animal interactions and productivity of commertial dairy cows. J Anim Sci. 78, 28212831, 2000.

19. Howie RI, Thorsen J, (1981). Identification of a strain of infectious bursal disease virus isolated from mosquitoes. Can J Comp Med. 45, 315-320.

20. Jackwood DJ, Sommer SE, (1999). Restriction fragment length polymorphisms in the VP2 gene of infectious bursal disease viruses from outside the United States. Avian Dis, 43, 310-314.

21. Kandil M, (1978). Hastalıkl piliçlerin bursa Fabricilerinde bir enfeksiyöz bursitis virusun izolasyonu ve bazı özel- 
likleri üzerinde araștırmalar. Yüksek Lisans tezi, Firat Üniversitesi Sağlık Bilimleri Enstitüsü, Elazığ.

22. Lasher HN, Shane SM, (1994). Infectious bursal disease. World Poultry Sci. 50, 133-166.

23. Lasher HN, Davis VS, (1997). History of infectious bursal disease in the USA. The first two decades. Avian Dis. 41, 11-19.

24. Leong JC, Brown D, Dobos P, Kibenge FSB, Ludert JE, Muller H, Mundt E, Nicholson B, (2000). Family Birnaviridae. Virustaxonomy: classification and nomenclature of viruses. Seventh report of the International Committee on Taxonomy of Viruses. Van Regenmortel MHV, Fauquet CM, Bishop DHL, Carstens EB, Estes MK, Lemon SM, Maniloff J, Mayo MA, McGeoch DJ, Pringle CR, andWickner RB. eds.Academic Press, San Diego, California, USA, p.481-490.

25. Lukert PD, Saif YM, (2003). Infectious bursaldisease. Diseases of Poultry. Calnek BW, Barnes HJ, Beard CW, McDougald LR, Saif YM, eds. 11th ed. Iowa State University Press, Ames, Iowa, USA, p.161-180.

26. Lütticken D, (1997). Viral Diseases of the immune system and strategies to control infectious bursal disease by vaccination. Acta Vet Hung. 45, 239-249.

27. Marquardt WW, Johnson RB, Odenwald WF, Schlotthober BA, (1980). An indirect enzyme-linked immuno sorbent assay (ELISA) for measuring antibodies in chickens infected with infectious bursal disease virus. Avian Dis. 24, 375385.

28. McFerran JB, McNulty MS, McKillop ER, Connor TJ, McCracken RM, Collins PS, Allan GM, (1980). Isolation and serological studies with infectious bursal disease viruses from fowl, turkeys and ducks, demonstration of a second serotype. Avian Pathol. 9, 395-404.

29. Moraes HLS, Salle CTP, Padilha AP, Nascimento VP, Souza GF, Pereira RA, Artencio JO, Salle FO, (2004). Infectious bursal disease: evaluation of pathogenicity of commercial vaccines from Brazil in specific pathogen free chichens. Brazil J Poult Sci. 6, 243-247.

30. Morton DJ, Anderson E, Foggin CM, Kock MD, Tiran EP, (1995). Plasma cortisol as an indicator of stress due to capture and translocation in wildlife species. Vet Rec.136, 60-63.

31. Okoye JOA, Uche UE, (1986). Serological evidence of infectious bursal disease virus infection in wild rats. Acta Vet Brno. 55, 207-209.
32. Pages-Mante A, Torrents D, Maldonado J, Saubi N, (2004). Dogs as potential carriers of infectious bursal disease virus. Avian Pathol.33, 205-209.

33. Rosenberger JK, Cloud SS, (1986). Isolation and characterization of variant infectious bursal disease viruses. J Am Vet Med Assoc.189, 357.

34. Sayım Y, Akman A, Girgin H, (1988). Ankara Bölgesi kümes hayvanlarinda IB, ILT, EDS, IBD, AE, ve adenovirus enfeksiyonlarının epizootiyolojik araştırılması ve izolasyon çalışmaları. Etlik Vet Mikrobiyol Derg. 6, 83-94.

35. Sharma JM, Kim L, Rautemschlein S, Yeh H, (2000). Infections bursal disease virus of chickens: pathogenesis and immunosupression. Dev Comp Immunol. 24, 223-235.

36. Shirai L, Seki R, Kamimura R, Mitsubayashi S, (1994). Effects of invert soap with $0.05 \%$ sodium hydroxide on infectious bursal disease virus. Avian Dis. 38, 240-243.

37. SnedekerC, Wills FK, Moulthrop IM, (1967). Some studies on the infectious bursal disease agent. Avian Dis. 11, 519-528.

38. Stoebel DP, Moberg GP, (1982). Repeated Acute Stress During the Follicular Phase and Luteinizing Hormone Surge of Dairy Heifers. J Dairy Sci. 65, 92-96.

39. Tsukamoto K, Tanimura N, Hihara H, Shirai J, Imai K, Nakamura K, Maeda M, (1992). Isolation of virulent infectious bursal disease virus from field outbreaks with high mortality in Japan. J Vet Med Sci. 54, 153-155.

40. Tsukamoto K, Tanimura N, Kakita S, Ota K, Mase M, Imai $\mathrm{K}$, Hihara H, (1995). Efficacy of three live vaccines against highly virulent infectious bursal disease virus in chickens with or without maternal antibodies. Avian Dis. 39, 218229

41. Türe O, Çöven F, (1999). SDS-PAGE ve western immunoblotting teknikleri kullanarak Türkiye'de izole edilen çok virulent infeksiyöz bursal hastalığ viruslarının karşılaştırmalı analizi. Turkish J Vet Anim Sci. 23, 83-92.

42. Van Den Berg TP, (2000). Acute infectious bursal disease in poultry: a review. Avian Pathol. 29, 175-194.

43. Van Den Berg TP, Meulemans G, (1991). Acute infectious bursal disase in poultry: protection afforded by maternally derived antibodies and interference with live vaccination. Avian Pathol. 20, 409-421. 